УДК 563.123

doi: $10.17223 / 19988591 / 33 / 7$

\title{
Е.В. Полковникова
}

Национальный исследовательский

Томский государственный университет, г. Томск, Россия

\section{Классификация фораминифер надсемейства Ammodiscoidea}

\begin{abstract}
Представлено переописание надсемейства Ammodiscoidea. В предложенной автором классификации отряда Amтоdiscida надсемейство объединяет фораминиферы со свободными раковинами в составе четырех семейств: Ammovolumminidae; Ammovertellinidae; Ammodiscidae (Glomospirellinae, Ammodiscinae); Turritellellidae (Turritellellinae, Usbekistaniinae). Микропалеонтологическая классификация надсемейства отличается ранее не использованными исследователями изменениями и дополнениями. Изменением явилось исключение из состава надсемейства форм с прикрепленной раковиной. Дополнением стало уточнение объема ранее установленных таксонов. Указаны основные признаки, приводятся синонимика и переописание ранее установленных надсемейства, семейств и подсемейств. Определено таксономическое положение родов и распространенных в юрских отложениях Западной Сибири стратиграфически важных видов надсемейства.
\end{abstract}

Ключевые слова: фораминиферы; Ammodiscoidea; классификация; состав; распространение; Западная Сибирь.

\section{Введение}

Проблемы классификации фораминифер имеют большое практическое значение. До настоящего времени являются дискуссионными и остаются нерешенными вопросы определения ранга фораминифер, выбора концепции, применения основных принципов систематики и подходов к выделению таксонов, построения классификации фораминифер в определенной иерархии. Особую актуальность вопросы о критериях вида, рода и более высоких таксономических единиц надсемейства Ammodiscoidea Reuss, 1862 приобретают в связи с выполнением последовательных описаний, с синонимикой, указанием основных признаков, типовых видов, с уточнением состава родов, определением систематического положения ранее установленных и новых таксонов, с уточненными данными по стратиграфическому распространению.

Первоначально семейство Ammodiscinea было выделено А. Рейссом [1] как группа фораминифер с песчано-кремневой раковиной, состоящей из одной трубчатой спирально-свернутой камеры. Позже Л. Румблер [2] отнес к семейству Ammodisculinidae трубчатые, спирально-свернутые, агглютинированные формы как с прободенной известковистой, так и с непрободенной 
кремнистой стенкой. Работы по классификации семейства Ammodiscidae и надсемейства Ammodiscoidea продолжены Дж. Кушманом [3], Ф. Чепмэн, В. Парр и А. Коллинсом [4]. В 1958 г. А.В. Фурсенко [5] впервые выделил отряд Ammodiscida. Он придавал ему большое значение как отряду, у которого в строении раковины появились септация и спиральность, обусловившие в процессе дальнейшей эволюции всё многообразие типов строения раковин. Первоначально отряд Ammodiscida выделялся в объеме трех семейств - Ammodiscidae, Tournayellidae, Lituolidae [5], позже их ранг повысился до надсемейств [6]. В этом составе отряд описан В.Ф. Козыревой в монографии «Фораминиферы верхнеюрских отложений Западной Сибири» [7]. В классификациях фораминифер, выполненных А.А. Григялисом [8], Л.С. Алексейчик-Мицкевич, 3.И. Булатовой [9], по-прежнему ранг фораминифер определялся как подкласс, но отряд Ammodiscida принимался уже в объеме двух надсемейств: Ammodiscacea Reuss, 1862, Lituolacea Blainville 1825. В работах В.И. Михалевич [10] и Х.М. Саидовой [11] фораминиферам придается ранг подтипа. X.M. Саидова принимает отряд Ammodiscida в объеме одного надсемейства Ammodiscidea Reuss, 1862 и выделяет в его составе четыре семейства, три из которых новые, группируя в семействах как свободные, так и прикрепленные раковины. Американские микропалеонтологи А. Леблик и Х. Таппан в широко используемой до настоящего времени классификации 1987 г. [12] описывают надсемейство Ammodiscacea в объеме одного семейства Ammodiscidae и пяти подсемейств. В монографии, посвященной фораминиферам верхней юры и неокома Западной Сибири [13], отряд Ammodiscida описан на основе классификации, опубликованной во «Введении в изучение фораминифер» [9]. В работах Н.И. Маслаковой [14], М.В. Вдовенко, Д.М. Раузер-Черноусовой и соавт. [15], Д. Лии и соавт. [16], М. Каминским [17], Э.М. Бугровой [18], В.М. Подобиной [19] фораминиферам придается ранг класса. Наиболее полной является классификация отряда Ammodiscida c описанием трех семейств прежнего надсемейства Ammodiscacea, выполненная Д.М. Раузер-Черноусовой [15. С. 47-52].

В статьях последних лет Я. Павловским, М. Хольцманн, Я. Тышка [20] на основании молекулярного филогенетического изучения представлена надотрядная классификация фораминифер в ранге типа, в которой род Аттоdiscus и семейство Ammodiscidae помещены в отряд Spirillinida (Hohenegger and Piller, 1975) emend Pawlowski, Holzmann, Tyszka, 2013 нового класса Tubothalamea Pawlowski, Holzmann, Tyszka, 2013. В.И. Михалевич [21] продолжила описывать свою систему 1992-2000 гг., в которой фораминиферам определен ранг типа, и определяет доминирующее значение признаку морфологии раковины, а составу и ультраструктуре стенки придает хотя и важное, но второстепенное значение. В.И. Михалевич строит систему на уровне более высоких таксонов, помещая представителей прежнего надсемейства Ammodiscaceа в подкласс Ammodiscana Mikhalevich, 1980 класса Spirillinata Mikhalevich, 1992 в объеме двух отрядов - Ammodiscida Mikhalevich, 1980 и 
Ammovertellinida Mikhalevich, 1999, указывая состав семейств и не определяя состав более низких таксонов.

В связи с пересмотром значимости основных признаков отряда Ammodiscida [22], в котором прикрепленные или частично прикрепленные раковины были объединены в надсемейство Tolypamminoidea Cushman, 1928, а свободные раковины были сгруппированы в надсемейство Ammodiscoidea Reuss, 1862 , объем надсемейства и описанных ранее разными авторами в его составе таксонов изменился и требует ревизии и переописания. Целью настоящей работы является определение и установление таксономического положения родов и видов фораминифер надсемейства Ammodiscoidea, широко распространенных и стратиграфически важных для юрских отложений Западной Сибири, с учетом понимания микропалеонтологами ранга фораминифер как класса и группы двухкамерных фораминифер спирального строения со второй псевдотрубчатой или (и) трубчатой неподразделенной камерой и агглютинированной кремнистой стенкой как отряда Ammodiscida [22].

\section{Материалы и методики исследования}

Объект настоящего изучения - раковины фораминифер надсемейства Ammodiscoidea. Материалом послужили коллекции раковин фораминифер и результаты исследования разрезов скважин Западной Сибири, полученные автором в ходе проведения научно-исследовательских работ в лаборатории микропалеонтологии ТГУ начиная с 1996 г. При извлечении раковин из породы использовалась стандартная методика сплавления с гипосульфитом [23]. Для изучения и фотографирования внешней морфологии раковин автором применялись бинокулярный стереоскопический микроскоп Carl Zeiss Stemi 2000-С и фотокамера Canon PowerShot A620. Для уточнения строения раковины использован сканирующий электронный микроскоп VEGA II LMU (ЦКП «Аналитический центр геохимии природных систем» ТГУ). Для изучения онтогенетической изменчивости у раковин производился подбор возрастных рядов. Внутреннее строение раковин исследовалось и фотографировалось при смачивании глицерином на прозрачном стекле и белом фоне в отраженном свете. Наименование таксонов производилось согласно правилам «Международного кодекса зоологической номенклатуры» [24]. Построение описаний таксонов осуществлялось по рекомендациям И.А. Коробкова [25]. Описание рассматриваемых таксонов надсемейства Ammodiscoidea выполнила автор статьи, опираясь на работы Д.М. Раузер-Черноусовой [15] и А. Леблик и X. Таппан [12], поэтому часть используемой литературы для синонимики, ввиду ограничения объема публикации, в списке литературы не приводится. Видовой состав фораминифер и их распространение приводятся не полностью вследствие ограничения местонахождения в юрских отложениях Западной Сибири. Изображение изученных родов и видов надсемейства представлено в виде фотографий в таблице. 
ТАБЛИЦА [PLATE]

Фораминиферы надсемейства Ammodiscoidea

[Foraminifera from the superfamily Ammodiscoidea]

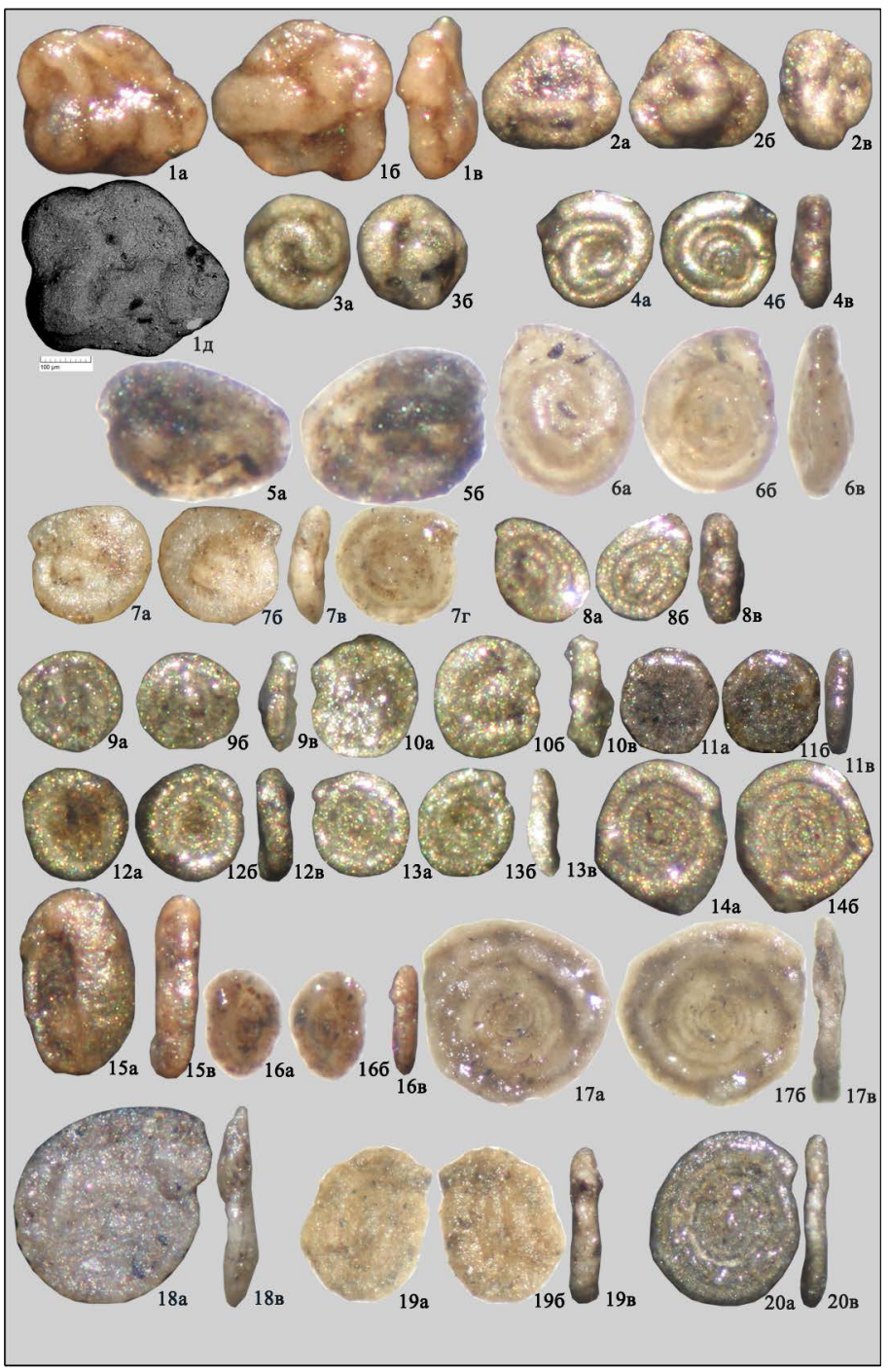

ПОЯСНЕНИЯ К ТАБЛИЦЕ

Коллекция хранится в лаборатории микропалеонтологии ТГУ под № 128-1/. Все экземпляры из местонахождений Западной Сибири: Приуральского (фиг. 17); ФроловскоТамбейского (фиг. 1; 11); Пурпейско-Васюганского (фиг. 2; 3; 7; 12; 13; 14; 15; 16; 19); Сильгинского (фиг. $4 ; 5 ; 6 ; 8 ; 9 ; 10 ; 18$ ) и Ажарминского районов (фиг. 20). Принятые обозначения: а - боковая сторона; б - противолежащая сторона; в - вид с периферического края; г - просветленная глицерином раковина; д - S.Е.М. микрофотография. 
Название и нумерация зон приводятся согласно стратиграфической схеме келловея и верхней юры Западной Сибири [41]. Ammovertellinidae. Фиг. 1 а, б, в, д; 2 a, б, в; 3 a, б. Glomospira oxfordiana Scharovskaja: 1 - экз. №128-1/Г32-4/1, ×46; скв. Герасимовская 32, гл. 2 703,35 м; верхний келловей, f-зона Dorothia insperata, Trochammina rostovzevi JF25; 2 - экз. №128-1/С-В18-10/3a, ×46; скв. Северо-Васюганская 18, гл. 2 290,25 м; средняя часть верхнего оксфорда, f-зона Recurvoides disputabilis JF37; 3 - экз. №128-1/C-B18-10/3, ×34; там же. Ammodiscidae (Glomospirellinae). Фиг. 4 а, б, в; 5 а, б; 6 а, б, в. Glomospirella semiaffixa Scharovskaja: 4 - экз. №128-1/Б106-3/6, ×45; скв. Болтная 106, гл. 2484,15 м; средний - основание верхнего оксфорда, f-зона Ammodiscus thomsi, Tolypammina svetlanae JF35; 5 - экз. №128-1/К17-1/6, ×76; скв. Казанская 17, гл. 2496,93 м; там же; 6 - экз. №128-1/Л4-1/3, ×44; скв. Линейная 1, гл. 2572,5 м; средняя часть верхнего оксфорда, f-зона JF37. Фиг. 7 а, б, в, г; 8 а, б, в. Glomospirella galinae Sharovskaja: 7 - экз. №128-1/128-1/ЮТ135-3/1, ×24; скв. Южно-Табаганская 135, гл. 2608,8 м; средний - основание верхнего оксфорда, f-зона JF35; 8 - экз. №128-1/Б106-3/5, ×47; скв. Болтная 106, гл. 2484,15 м; там же. Фиг. 9 а, б, в; 10 а, б, в. Glomospirella otorica Romanova: 9 - экз. №128-1/O152-4/1, ×40; скв. Олимпийская 152, гл. 2436,0 м; нижний кимеридж, комплекс с Glomospirella otorica; 10 - экз. №128-1/O152-4/2, ×43; там же. Ammodiscidae (Ammodiscinae). Фиг. 11 а, б, в. Ammodiscus uglicus Ehremeeva subsp. uglicus Ehremeeva. Экз. №128-1/Ен-Ях612-1/1, ×29; скв. Ен-Яхинская 612, гл. 3984,6 м; верхи верхнего бата - нижний келловей, f-слои с Ammodiscus uglicus JF26. Фиг. 12 а, б, в; 13 а, б, в; 14 а, б. Ammodiscus uglicus Ehremeeva subsp. ehremeevae Dain: 12 - экз. №128-1/И3-12/1, ×48; скв. Игольская 3, гл. 2790,2 м; нижний оксфорд, f-зона Ammobaculites tobolskensis, Trochammina oxfordiana JF34; 13 - экз. №1281/Ю-М27-6/2, ×42; скв. Южно-Мыльджинская 27, гл. 2577,6 м; средний - основание верхнего оксфорда, f-зона JF35; 14 - экз. №128-1/Б106-3/1, ×46; скв. Болтная 106, гл. 2484,15 м; там же. Фиг. 15 а, в; 16 а, б, в. Ammodiscus aff. southeyensis Wall: 15 - экз. №128-1/И3-12/3, ×47; скв. Игольская 3, гл. 2 790,2 м; нижний оксфорд, f-зона JF34; 16 - экз. №128-1/И3-12/6, ×43; там же. Фиг. 17 а, б, в. Ammodiscus thomsi Chamney. Экз. №128-1/M11203-7/1, ×20; скв. Мапасийская 11203, гл. 1 335,13 м; средний - основание верхнего оксфорда; f-зона JF35 (из коллекции Л. К. Левчук). Фиг. 18 а, в; 19 а, б, в. Ammodiscus cheradospirus Loeblich et Tappan: 18 - экз. № 128-1/К124-1/3, ×32; скв. Казанская 124, гл. 2884,62 м; то же, там же; $19-$ экз. № 128-1/Bec 247-2/1, ×28; скв. Весенняя 247, гл. 2561,7 м; то же, там же. Фиг. 20 а, в. Ammodiscus veteranus Kosyreva. Экз. № 128-1/В2-1/4, ×23; скв. Ванжильская 2, гл. 2 040,9 м; верхи средневолжского - низы верхневолжского подъяруса; f-зона Ammodiscus veteranus, Evolutinella emeljanzevi JF52 (из коллекции Г.М. Татьянина). Микрофотографии Е.В. Полковниковой. S.Е.М. микрофотография Е.В. Корбовяк. 


\section{[NOTES TO THE PLATE}

The collection is stored in the Laboratory of Micropaleontology, TSU, collection № 128-1/. All specimens are from West Siberia: Priuralsk (фиг. 17); Frolovsko-Tambeysk (fig. 1; 11); Purpeisk-Vasyugansk (fig. $2 ; 3 ; 7 ; 12 ; 13 ; 14 ; 15 ; 16 ; 19$ ); Silgin (fig. $4 ; 5 ; 6 ; 8 ; 9 ; 10 ; 18$ ) and Azharmin Facies Regions (fig. 20). The accepted designations: a - lateral view; $\sigma$ - the opposed side; в - peripheral view; $г$ - clarified shell in glycerin; д - S.E.M. microphotography. Zone names and numbers f-Zone are given in accordance with Stratigraphic Charts for the Callovian and Upper Jurassic of Western Siberia [41]. Ammovertellinidae. Fig. 1 а, б, в, д; 2 а, б, в; 3 а, б. Glomospira oxfordiana Scharovskaja: 1 - specimen № 128-1/Г32-4/1, ×46; Gerasimovskaya 32 Borehole, depths 2703,35 m; Upper Callovian, f-Zone Dorothia insperata, Trochammina rostovzevi JF25; 2 - specimen № 128-1/C-B18-10/3a, ×46; Severo-Vasyuganskaya 18 Borehole, depths 2290,25 m; middle part Upper, f-Zone Recurvoides disputabilis JF37; 3 - specimen № 128-1/C-B18-10/3, $\times 34$; ibidem. Ammodiscidae (Glomospirellinae). Fig. 4 a, б, в; 5 а, б; 6 а, б, в. Glomospirella semiaffixa Scharovskaja: 4 - specimen № 128-1/Б106-3/6, ×45; Boltnaya 106 Borehole, depths 2484,15 m; Middle - lowermost Upper Oxfordian, f-Zone Ammodiscus thomsi, Tolypammina svetlanae JF35; 5 - specimen № 1281/К17-1/6, ×76; Kazanskaya 17 Borehole, depths 2496,93 m; ibidem; 6 - specimen № 128-1/Л4-1/3, ×44; Lineynaya 1 Borehole, depths 2572,5 m; middle part Upper Oxfordian, f-Zone JF37. Fig. 7 a, б, в, г; 8 a, б, в. Glomospirella galinae Sharovskaja: 7 - specimen №128-1/128-1/Ю-T135-3/1, ×24; Yuzhno-Tabaganskaya 135 Borehole, depths 2608,8 m; Middle - lowermost Upper Oxfordian, f-Zone JF35; 8 - specimen № 128-1/ 5106-3/5, ×47; Boltnaya 106 Borehole, depths 2484,15 m; ibidem. Fig. 9 а, б, в; 10 а, б, в. Glomospirella otorica Romanova: 9 - specimen № 128-1/O152-4/1, ×40; Olimpiyskaya 152 Borehole, depths 2436,0 m; Lower Kimmeridgian, complex with Glomospirella otorica; 10 - specimen № 128-1/O152-4/2, ×43; ibidem. Ammodiscidae (Ammodiscinae). Fig. 11 a, б, в. Ammodiscus uglicus Ehremeeva subsp. uglicus Ehremeeva. Specimen № 128-1/Ен-Ях612-1/1, ×29; En-Yakhinskaya 612 Borehole, depths 3984,6 m; uppermost Upper Bathonian - Lower Callovian, Beds with Ammodiscus uglicus JF26. Fig. 12 a, б, в; 13 а, б, в; 14 а, б. Ammodiscus uglicus Ehremeeva subsp. ehremeevae Dain: 12 - specimen № 128-1/И3-12/1, ×48; Igol'skaya 3 Borehole, depths 2790,2 m; Lower Oxfordian, f-Zone Ammobaculites tobolskensis, Trochammina oxfordiana JF34; 13 - specimen № 128-1/Ю-M27-6/2, ×42; Yuzhno-Myl'dzhinskaya 27 Borehole, depths 2577,6 m; Middle - lowermost Upper Oxfordian, f-Zone JF35; 14 - specimen № 128-1/Б106-3/1, ×46; Boltnaya 106 Borehole, depths 2 484,15 m; ibidem. Fig. 15 а, в; 16 а, б, в. Ammodiscus aff. southeyensis Wall: 15 - specimen № 128-1/И3-12/3, ×47; Igol'skaya 3 Borehole, depths 2790,2 m; Lower Oxfordian, f-Zone JF34; 16 specimen № 128-1/И3-12/6, ×43; ibidem. Fig. 17 а, б, в. Ammodiscus thomsi Chamney. Specimen № 128-1/ M11203-7/1, ×20; Mapasiyskaya 1203 Borehole, depths 1335,13 m; Middle - lowermost Upper Oxfordian; f-Zone JF35 (from LK Levchuk's collection). Fig. 18 a, в; 19 a, б, в. Ammodiscus cheradospirus Loeblich et Tappan: 18- specimen № 128-1/K124-1/3, ×32; Kazanskaya 124 Borehole, depths 2884,62 m; ibidem; 19 specimen № 128-1/Bec247-2/1, ×28; Vesennyaya 247 Borehole, depths2561,7 m; ibidem. Fig. 20 а, в. Ammodiscus veteranus Kosyreva. Specimen № 128-1/B2-1/4, ×23; Vanzhil'skaya 2 Borehole, depths 2 040,9 m; uppermost Middle - lowermost Upper Volgian; f-Zone Ammodiscus veteranus, Evolutinella emeljanzevi JF52 (from GM Tatyanin's collection). Microphotography by EV Polkovnikova. S.E.M. microphotography by EV Korbovyak] 


\section{Результаты исследования и обсуждение}

На основе определения и переоценки веса классификационных критериев - морфологического (биологический критерий органического развития), дискретности - и диагностических признаков (тип строения = тип навивания, форма) автор предлагает уточнить таксономический состав и объемы установленных ранее надсемейства Ammodiscoidea, семейств и подсемейств отряда Ammodiscida [11; 12; 15; 17]. Определены четыре основных типа спирального строения раковин, обусловивших выделение семейств в надсемействе: 1) изогнутые или скрученные, или навитые незавершенной спиралью, или с одним оборотом; 2) неправильно клубковидные; 3) спирально-плоскостные; 4) спирально-конические. Тип строения раковины, обусловленный основным типом навивания второй псевдотрубчатой и (или) трубчатой камеры, является основным морфологическим критерием для выделения семейств, а его разновидности позволят провести разделение на подсемейства.

Класс Foraminifera d'Orbigny, 1826

Подкласс Textulariata Mikhalevich, 1980

Отряд Ammodiscida Fursenko, 1958 [5. C. 23], emend. Polkovnikova, 2015 [22]

Надсемейство Ammodiscoidea Reuss, 1862 emend. Polkovnikova, hic

(nom. transl. Chapman, Parr, Collins, 1934 [4. P. 556]

ex Ammodiscinea Reuss, 1862 [1. P. 365])

Ammodiscacea part.: Loeblich, Tappan, 1961. P. 275; 1984. P. 7; 1987. P. 46; Kaminski, 2004. P. 245; Ammodiscoidea part.: Chapman, Parr, Collins, 1934. P. 556; Ammodiscidea part.: Даин, Основы палеонтологии..., 1959. С. 180-183; Козырева, Фораминиферы верхнеюрских..., 1972. С. 30; Саидова, 1981. С. 15.

Д и а г н о з. Раковины свободные. Начальная камера неясно отчлененная или отчетливая, шаровидная или субшаровидная. Вторая камера трубчатая или псевдотрубчатая, неподразделенная, поверхность со случайными поперечными сжатиями роста, короткая с быстрым расширением или длинная с постепенным расширением. Обычно раковины эволютные. Изогнутые, скрученные или навитые незавершенной спиралью, или с навиванием различного типа - неправильно клубковидные, спирально-плоскостные (планиспиральные или стрептоспиральные), спирально-конические (трохоспиральные (трохоидные) или спирально-винтовые) и (или) комбинированные. В поздней стадии роста часть раковины может быть выпрямленной или изогнутой неправильно или зигзагообразно. Стенка раковины агглютинированная, агглютинат преимущественно из зерен кварца, реже других минералов с секреционным цементом. Цемент у современных форм органический [26]. Устье обычно простое, расположено в открытом конце трубчатой или псевдотрубчатой камеры. У форм с дихотомически разветвленной второй камерой устье сложное, расположено в открытом конце трубчатых камер. 
С о с т а в. 4 семейства: Ammovolumminidae Chernykh, 1967; Ammovertellinidae Saidova, 1981; Ammodiscidae Reuss, 1862; Turritellellidae Saidova, 1981. В о з р а с т. Ранний кембрий - голоцен.

Семейство Ammovolumminidae Chernykh, 1967, emend. Polkovnikova, hic (nom. transl. Pojarkov, 1979 [27. C. 63] ex Ammovolummininae Tschernich, 1967 [28. C. 38]; nom. correct. Rauser 1993 [15. C. 47])

Ammovolummininae part.: Черных, 1967. C. 38; Loeblich, Tappan, 1984. P. 7; 1987. P. 46; Ammovolumminidae part.: Поярков, 1979. С. 63; nom. correct., Rauser, 1993. C. 47; Lituiforminoidinae part.: Саидова, 1981. C. 16 (subfam.: name not available, ICZN [24. С. 56. Ст. 13.1]. Для подсемейства типовым выбран род Lituiforminoides Saidova, 1981 - типовой вид Trochammina lituiformis Brady, 1879, являющийся типовым видом для рода Lituotuba Rhumbler, 1895 [12. Р. 69].

Д и а г н о з. Раковины свободные. Изогнутые, скрученные или навитые незавершенной спиралью, или с одним оборотом. Начальная камера иногда неясно отчлененная. Вторая камера трубчатая, короткая, с довольно быстрым расширением, изогнутая или скрученная. В ранней стадии роста навита незавершенной спиралью или с одним оборотом. По форме в виде короткого конуса (слабоизогнутые, сильноизогнутые) или булавовидные. Раковины различного очертания: короткоконусовидные (скрученные или изогнутые) с быстрым расширением второй короткой камеры, или вначале округлые, или короткокрючкообразно изогнутые, в поздней стадии прямолинейно удлиненные. Устье простое в открытом конце трубчатой камеры. Р од о в о й с о с т а в и р ас п р ос т р а н е н и е. 4 рода: Hyperbathoides Ireland, 1966 (нижний - средний силур) [15]; Ammovolummina Chernykh, 1967 (средний силур - нижний девон) [29]; Tubacera Chernykh, 1979 (нижний девон) [15]; Psammonyx Doderlein, 1892 (силур - голоцен) [11. С. 16; 15; 22. Рис. 1]. 3 а м е ч а н и я. Описание семейства дано по Раузер-Черноусовой [15. С. 47] с уточнением автора, а дополнением явилось то, что к семейству Ammovolumminidae отнесены роды, имеющие свободную раковину. В о з р а с т. Силур - ранний девон, голоцен.

Т и п о в о й р о д: Ammovolummina Chernykh, 1967 [28. С. 39]. Т и п о в о й в и д: Ammovolummina saumensis Chernykh, 1967, нижний девон, восточный склон Урала, голотип [28; 15. Рис. 8, а, б].

Семейство Ammovertellinidae Saidova, 1981, emend. Polkovnikova, hic

Ammoverlellinidae part.: Саидова, 1981. С. 15; Ammovertellininae part.: Саидова, 1981. С. 16; Loeblich, Tappan, 1987. Р. 50; Раузер-Черноусова, 1993. С. 50; Kaminski, 2004. P. 245; Glomospirellinae part.: Ciarapica, Zaninetti, 1985. P. 307.

Д и а г н о з. Раковины свободные, неправильно клубковидные или комбинированные. Нарастание второй камеры происходит без определенного порядка, неправильно клубковидно, с сигмоидальной стадией, в нескольких направлениях, стрептоспирально или комбинированно. В поздней стадии роста часть раковины может быть выпрямленной или изогнутой неправильно 
или зигзагообразно. По форме: мономорфные - в виде клубка неправильной формы, субсферические, овоидные, уплощенно-овоидные, угловато-овоидноуплощенные; гетероморфные - в ранней стадии в виде клубка неправильной формы, или дисковидные. В поздней стадии - в виде трубки, выпрямленные, прямолинейно удлиненные или изогнутые: S-образно, U-образно. По очертанию угловато-округлые или угловато-овальные, или округлые, или овальные, или иррегулярно-U-образные. Устье простое в открытом конце псевдотрубчатой или трубчатой камеры. Р од о в о й с о с тав и расп п ост ран ен ие. 5 родов: Glomospira Rzehak, 1885 (силур - голоцен) [15. С. 50]; Ammovertellina Suleimanov, 1959 (нижний карбон - голоцен) [29. С. 85]; Rectoglomospira Trifonova, 1978 (триас) [29. С. 95]; Thalmannina Majzon, 1943 (верхний мел, Украина) [12; 22. Рис. 1]; Gandinella Ciarapica et Zaninetti, 1985 (триас) [30].

3 а м е ч а н и я. Х.М. Саидова [11] выделила семейство Ammovertellinidae на том основании, что «вторая камера в начале свернута стрептоспирально», и отнесла к подсемейству Ammovertellininae 4 рода (Ammovertellina, Glomospira, Glomospirella Plummer, 1945, Thalmannina) со свободной раковиной. Леблик и Таппан [12] добавили в состав подсемейства ещё 3 рода с кремнистой стенкой: Annectina Suleymanov, 1963; Pilamminella Salaj, 1978; Rectoglomospira. Род Pilamminella (средний - верхний триас) [12] с известковой гранулярной стенкой без признаков агглютинированных частиц был удален из списка родов [29. Р. 94]. Раузер-Черноусова [15], понизив ранг семейства до подсемейства, относила к нему свободные и прикрепленные раковины с «клубкообразным» навиванием в ранней стадии роста, в поздней стадии часть раковины изогнута неправильно или зигзагообразно, с плотным прикасанием оборотов, и включила в состав подсемейства 2 рода: Ammovertellina (свободные) и Ammovertella Cushman, 1928 (прикрепленные) = Ammodiscus (Psammophis) inversus Schellwien, 1898. Другие роды - Glomospira, Glomospirella - были отнесены к подсемейству Glomospirellinae Ciarapica, Zaninetti, 1985.

Описание семейства уточнено автором, а дополнением явилось то, что автор статьи предлагает изменить объем семейства Ammovertellinidae [11], включив в него свободные раковины, неправильно клубковидные и (или) комбинированные, с раковиной в виде клубка неправильной формы - с неправильно клубковидным навиванием в ранней стадии роста, субсферической, овоидной, уплощенно-овоидной формы, в поздней стадии роста - в виде трубки, выпрямленные, прямолинейно удлиненные или изогнутые, исключая из семейства раковины со спирально-плоскостным (стрептоспиральным) навиванием только дисковидной формы. Раковины родов Glomospirella, Annectina дисковидной формы автор включает в подсемейство Glomospirellinae семейства Ammodiscidae Reuss, 1862. По сравнению с классификацией Раузер-Черноусовой [15] автор исключает прикрепленные раковины из семейства. Прикрепленные раковины рода Ammovertella предлагается отнести к семейству Ammodiscellinidae Saidova, 1981 [22]. В о з р а с т. Силур - голоцен. 
Т и п о в о й р о д: Ammovertellina Suleimanov, 1959. Ammovertellina: Сулейманов, 1959. С. 19; Hemigordiellina: Marie, in Deleau and Marie, 1961. Р. 76; типовой вид: Glomospira diversa Cushman et Waters, 1930. Р. 42 [12. P. 50]. Т и п о в о й в и д: Ammovertellina prima Suleymanov, 1959, палеоцен, Средняя Азия, Кызылкумы, голотип [31. С. 19-20. Рис. 1, а, б; 12. P1. 39. Fig. 2, 3; 15. С. 51. Табл. IX. Фиг. 10]. В о з р а с т. Ранний карбон (ранний визейский век) - голоцен [12. Р. 50; 29].

Р о д Glomospira Rzehak, 1885. Т и п о в о й в и д (по автору рода): Trochammina squamata Jones et Parker, 1860 var. gordialis Jones et Parker, 1860, современный, Индийский океан, голотип [Jones et Parker, 1860. P. 304]. Т и п о в о й в и д (предлагается автором): Glomospira gordialis (Jones et Parker), 1860, современный, Атлантический океан [12. P1. 38. Fig. 5-6; 15. С. 50. Табл. IX. Фиг. 6]. Glomospira: Rzehak, 1885. P. 126; Chushman, 1928. P. 102; Основы палеонтологии..., 1959. С. 180. non Рис. 93; Loeblich, Tappan, 1987. P. 50-51. P1. 38. Fig. 5, 6; Раузер-Черноусова, 1993. С. 50. Табл. IX. Фиг. 6; Gordiammina: Rhumbler. 1895. P. 84: type species: obj. Schellwien, 1898. P. 265; Ammodiscus (Gordiammina): Schellwien, 1898. P. 265 (nom. transl.); Arglomospirum: Rhumbler, 1913. Р. 387 (err. emend). Синонимика рода дана по Леблик и Таппан [12. Р. 50-51]. В и д о в ой с о с та в и р а п р о с ран ен и е. 3 вида: Glomospira perplexa Franke, 1936, синемюр [32. Табл. f-3. Фиг. 13]; Glomospira ex gr. gordialis (Jones et Parker, 1860), верхний плинсбах - основание тоара, нижний байос - низы нижнего келловея [32. Табл. f-3. Фиг. 14-16]; Glomospira oxfordiana Scharovskaja, 1966 (таблица, фиг. 1-3), верхний келловей - оксфорд Западной Сибири и севера Средней Сибири. С р а в н е н и е. Раковины Glomospira с одним последним оборотом, расположенным в одной плоскости, сходны с раковинами Glomospirella. Отличаются характером навивания (рыхлым, несколько свободным против плотного, правильного, последовательного), формой раковины (субсферической, овоидной, уплощенно-овоидной, угловато-овоидноуплощенной против дисковидной (плоской, слабо двояковыпуклой, слабо выпукло-вогнутой), очертанием раковины (угловато-округлым против правильного округлого или овального). От рода Repmanina Suleymanov, 1966 отличаются типом навивания (неправильно клубковидным против спирально-винтового - вокруг низкой вертикальной оси правильными последовательными оборотами, «как нитки на шпульке»), формой раковины (субсферической, овоидной, уплощенно-овоидной, угловато-овоидно-уплощенной против низкосубцилиндрической). В о з р а с т. Силур - голоцен.

Семейство Ammodiscidae Reuss, 1862, emend. Polkovnikova, hic

(nom. correct. Rhumbler, 1895 [2. P. 83]

ex Ammodiscinea Reuss, 1862 [1. P. 365])

Ammodiscinea part.: Reuss, 1862. P. 365; Ammodiscidae part.: Rhumbler, 1895. P. 83; Ammodiscida part.: Haeckel, 1894. P.185; Ammodisculinidae part.: Rhumbler, 1913. P. 339; Arammodisclidia part.: Rhumbler, 1913. P. 341; Ammodiscidae part.: Даин, Основы палеонтологии..., 1959. С. 180-182; Герке, 1960; 
Loeblich, Tappan, 1964. Р. С210; Волошинова и др., 1970; Козырева, Фораминиферы верхнеюрских..., 1972. С. 30; Саидова, 1981. С. 16; Loeblich, Tappan, 1984. Р. 7; 1987. Р. 46; Раузер-Черноусова, 1993. С. 49.

Д и а г н о з. Раковины свободные. Спирально-плоскостные со стрептоспиральным или планиспиральным навиванием или (и) комбинированные. В поздней стадии роста часть второй камеры выпрямляется или в последнем обороте разделяется на две с выпрямлением, или неправильно изогнута с неправильными изгибами по одной из поверхностей. Раковины эволютные или полуэволютные. По форме обычно мономорфные - дисковидные или гетероморфные - в ранней стадии дисковидные, в поздней стадии - в виде трубки, выпрямленные или изогнутые. По очертанию обычно только округлые и овальные, реже-с выпрямленной прямолинейной или изогнутой конечной частью. Стенка раковины агглютинированная, агглютинат кремнистый, с секреционным цементом. Устье обычно простое, расположено в открытом конце трубчатой или псевдотрубчатой камеры. У форм с дихотомически разветвленной второй камерой устье сложное, расположено в открытом конце трубчатых камер. С о с т а в. 2 подсемейства: Glomospirellinae Ciarapica, Zaninetti, 1985; Ammodiscinae Reuss, 1862. 3 а м е ч а н и я. Основной критерий разделения на подсемейства - преобладающий тип навивания второй длинной камеры. Стрептоспиральное навивание (определение дано автором статьи [22. С. 407]) для Glomospirellinae и планиспиральное - для раковин Ammodiscinae. В о з р а с т. Ранний кембрий - голоцен [29].

Подсемейство Glomospirellinae Ciarapica,

Zaninetti, 1985, emend. Polkovnikova, hic

Glomospirellinae part.: Ciarapica, Zaninetti, 1985. Р. 307; Раузер-Черноусова, 1993. С. 50.

Д и а г н о з. Раковины свободные, со спирально-плоскостным - стрептоспиральным навиванием или комбинированные. На ранней стадии роста стрептоспирально навитые - с небольшим колебанием плоскостей навивания или отклонением от планиспирального навивания, или неправильно клубковидные, или вторая камера навита вокруг низкой вертикальной оси правильными последовательными оборотами, «как нитки на шпульке» (Glomospirel$l a)$, или правильно клубковидные (Annectina); в поздней стадии роста вторая камера изменяет свое навивание на планиспиральное (по крайней мере, в последнем обороте). Или комбинированные: в поздней стадии роста часть раковины выпрямляется или неправильно изгибается. Раковины эволютные или полуэволютные. По форме: мономорфные - дисковидные, слабо двояковыпуклые, слабо выпукловогнутые; гетероморфные - в ранней стадии дисковидные, в поздней стадии - в виде трубки, выпрямленные или изогнутые. По очертанию обычно только округлые или овальные, реже - с выпрямленной прямолинейной или изогнутой конечной частью. Р о д о в о й с о с т а в и ра сп р о с т ран е н и е. 3 рода: Glomospirella Plummer, 1945 (нижний кембрий - нижний неоген (миоцен) [22; 29. P. 90]; Agathamminoides 
Vangerow, 1964 (карбон - пермь) [15. С. 50]; Annectina Suleymanov, 1963 (берриас - голоцен) [22. Рис. 1; 29. Р. 86]. 3 а м е ч а н и я. Первоначально авторы выделили подсемейство Glomospirellinae [30. Р. 307], указав лишь, что подсемейство «объединяет Ammodiscidae, навитые в клубке». РаузерЧерноусова [15] переописала подсемейство и отнесла к нему раковины «свободные, эволютные полностью или частично, клубкообразно плотно навитые или в комбинации со спирально-плоскостным навиванием, реже часть второй камеры выпрямленная или неправильно изогнутая; агглютинат обычно тонкозернистый» и включила в это подсемейство 3 рода: Glomospira, Agathamminoides, Glomospirella. Автор статьи по-прежнему придерживается диагноза подсемейства Раузер-Черноусовой 1993 г. [15], существенно его уточнив и расширив объем, а дополнением автора явилось исключение из подсемейства раковин с преобладающим неправильно клубковидным навиванием. Неправильно клубковидные раковины рода Glomospira отнесены к семейству Ammovertellinidae. В о з р а с т. Ранний кембрий - голоцен.

Т и п о в о й р о д: Glomospirella Plummer, 1945. Glomospirella: Plummer, 1945. P. 233; Loeblich, Tappan, 1987. P. 51. Pl. 38. Fig. 1-2; Раузер-Черноусова, 1993. С. 50. Табл. IX. Fig. 8; non Glomospirella: Рейтлингер, 1950. С. 27; Mjatliukaeina: Сулейманов, 1969. P. 51; Ammodiscus gaultinus: Berthelin, 1880. P. 19; Glomospirella (Usbekistania) part.: Сулейманов, I960. С. 18. Рис. 1. Фиг. 1, 2; Usbekistania part.: Loeblich, Tappan, 1987. P. 52. Pl. 39. Fig. 18, 19. Т и п о в о й в и д: Glomospira umbilicata Cushman, Waters, 1927, средний карбон, США [12. Pl. 38. Fig. 12; 15. С. 50. Табл. IX. Fig. 8]. В и д о в о й с о с т а в и р а с п р о с т ра н е н и е. 3 вида: Glomospirella semiaffixa Scharovskaja, 1966 (таблица, фиг. 4-6), верхний келловей - оксфорд; Glomospirella galinae Scharovskaja, 1966 (таблица, фиг. 7-8) [33. Табл. I. Фиг. 10-11], келловей - оксфорд; Glomospirella otorica Romanova, 1972 (таблица, фиг. 9-10) [33. Табл. I. Фиг. 14, 15], верхи верхнего оксфорда - кимеридж Западной Сибири. 3 а м е ч а н и я. С. Кульвер в 1991 г. публикует данные о первом появлении аммодисцид в отложениях нижнего кембрия Западной Африки и приводит изображение экземпляра, по его мнению, принадлежащего роду Glomospira [34. P. 691. Fig. 1 (C)]. Автор статьи считает, что этот экземпляр имеет спирально-плоскостное (стрептоспиральное) навивание, дисковидную форму и характерное для рода устье - в открытом конце псевдотрубчатой камеры, всё это диагностические признаки рода Glomospirella. Поэтому временем первого появления представителей рода Glomospirella следует считать ранний кембрий. В о з р а с т. Ранний кембрий - ранний неоген (миоцен) [15. C. 50; 29. Р. 90].

Подсемейство Ammodiscinae Reuss, 1862

(nom. transl. Rhumbler, 1904 [35. P. 275]

ex Ammodiscinea Reuss, 1862 [1. P. 365])

Ammodiscinae part.: Rhumbler, 1904. Р. 275; Саидова, 1981. С. 16; Loeblich, Tappan, 1987. P. 47; Раузер-Черноусова, 1993. C. 49; Kaminski, 2004. P. 245. 
Д и а г н о 3. Раковины свободные, со спирально-плоскостным - планиспиральным навиванием (Ammodiscus Reuss, 1862; Spirosolenites Glaessner, 1979) или комбинированные. В поздней стадии роста часть второй камеры выпрямляется (Rectoammodiscus Reitlinger, 1993) или в последнем обороте разделяется на две с выпрямлением (Bifurcammina Ireland, 1939); или неправильно изогнута с неправильными изгибами по одной из поверхностей (Hemidiscus Schellwien, 1898). По форме обычно мономорфные - дисковидные или гетероморфные - в ранней стадии дисковидные, в поздней стадии в виде трубки, выпрямленные или изогнутые. По очертанию обычно только округлые или овальные, реже - с выпрямленной прямолинейной или изогнутой конечной частью. Устье обычно простое, расположено в открытом конце трубчатой или псевдотрубчатой камеры. У форм с раздвоенной второй камерой (Bifurcammina) устье сложное, расположено в открытом конце двух трубчатых камер. Р о д о в о й с о с т а в и ра с п р о с т р а н е н и е. 5 родов: Amтоdiscus Reuss, 1862 (нижний кембрий - голоцен) [29. Р. 85]; Rectoammodiscus Reitlinger, 1993 (силур - карбон) [15. С. 49]; Bifurcammina Ireland, 1939 (силур - верхняя пермь) [15. С. 50]; Hemidiscus Schellwien, 1898 (карбон пермь, мезозой) [15. С. 50]; Spirosolenites Glaessner, 1979 (нижний кембрий) [12. Р. 49; 22. Рис. 1]. В о з р а с т. Ранний кембрий - голоцен.

Т и п о в о й р о д: Ammodiscus Reuss, 1862. Ammodiscus: Reuss, 1862. P. 365; Bornemann 1874. P. 724; Rhumbler, 1895. P. 83; Loeblich, Tappan. 1954. P. 308; Pokorny, 1958. Р. 175; Даин, Основы палеонтологии..., 1959. С. 178 181; Герке, 1960. С. 7; Герке, 1961. С. 121; Loeblich, Tappan, 1964. Р. С. 210; Волошинова и др., 1970. С. 49; Козырева, Фораминиферы верхнеюрских..., 1972. С. 34-35; Loeblich, Tappan, 1987. Р. 47-48; Раузер-Черноусова, 1993. C. 49; Involutina (part.): Terquem, 1862. P. 450; Arammodiscum: Rhumbler, 1913. Р. 387 (err. emend.); Grzybowskiella: Mjatliuk, 1970. Р. 70; типовой вид: Cornuspira angusta Friedberg, 1901. Р. 637. Т и п о в о й в и д: Ammodiscus infimus Bornemann, 1874 [Bornemann, 1874. P. 725] (= Involutina silicea Terquem, 1862) нижняя юра Франции, лектотип [12. Pl. 36. Fig. 1-2; 15. Табл. IX. Рис. 2]. В о $з$ р а с т. Ранний кембрий - голоцен [29. Р. 85]. В и д о в о й с о с т а в и р а с п р о с т р а н е н и е. 10 видов: Ammodiscus siliceus (Terquem, 1862), верхи нижнего - низы верхнего плинсбаха [32]; Ammodiscus glumaceus Gerke et Sossipatrova, 1961, низы нижнего тоара - верхи нижнего аалена [32]; Ammodiscus arangastachiensis Nikitenko, 1991, низы нижнего байоса - нижний оксфорд [32]; Ammodiscus uglicus Ehremeeva 1972 - 2 подвида Ammodiscus uglicus Ehremeeva, 1972 subsp. uglicus Ehremeeva, 1972 (таблица, фиг. 11), верхи верхнего бата - келловей [32]; Ammodiscus uglicus Ehremeeva, 1972 subsp. ehremeevae Dain, 1972 (таблица, фиг. 12-14) [33. Табл. I. Фиг. 1-3], оксфорд; Ammodiscus aff. southeyensis Wall, 1960 (таблица, фиг. 15-16), нижний оксфорд; Ammodiscus thomsi Chamney, 1971 (таблица, фиг. 17), оксфорд - кимеридж [32. С. 240]; Ammodiscus cheradospirus Loeblich et Tappan, 1950 (таблица, фиг. 18-19), верхи верхнего келловея - верхний оксфорд; Ammodiscus 
zaspelovae Kosyreva, 1972, волжский ярус [7]; Ammodiscus veteranus Kosyreva, 1972 (таблица, фиг. 20), верхи средневолжского подъяруса - низы нижнего берриаса Западной Сибири [32].

Семейство Turritellellidae Saidova, 1981, emend. Polkovnikova, hic

Turritellellidae: Саидова, 1981. С. 16; Usbekistaniidae part.: Вялов, 1968. С. 5.

Д и а г н о з. Раковины свободные, спирально-конические или комбинированные. Трохоспиральные (трохоидные) - вторая камера в ранней стадии роста навита вокруг вертикальной оси разной высоты (от низкой до высокой) или комбинированно - в ранней стадии трохоидно, в поздней стадии в одной плоскости. Спирально-винтовые - вторая камера в ранней стадии роста навита вокруг низкой вертикальной оси правильными последовательными оборотами, «как нитки на шпульке», или комбинированно. В поздней стадии роста часть второй камеры может быть навита в одной плоскости (1-2 оборота). По форме субтреугольные, низкосубцилиндрические, удлиненносубцилиндрические. По очертанию округлые, овальные или удлиненно-овальные. С о с т а в. 2 подсемейства: Turritellellinae Saidova, 1981; Usbekistaniinae Vyalov, 1968.

3 а м е ч а н и я. Спирально-конические (трохоспиральные (трохоидные) и спирально-винтовые) раковины объединяет семейство Turritellellidae. Описание семейства уточнено автором, а дополнением явилось то, что к семейству Turritellellidae отнесены роды, имеющие только свободную раковину (против свободных и прикрепленных у автора семейства), и то, что семейство было разделено на два подсемейства. Выделение подсемейств основывается на типе навивания второй псевдотрубчатой или трубчатой камеры. Раковины в ранней стадии роста, навитые трохоспирально, по форме субтреугольные или удлиненно-субцилиндрические, объединяет подсемейство Turritellellinae. Раковины, навитые вокруг низкой вертикальной оси правильными последовательными оборотами, «как нитки на шпульке», по форме низкосубцилиндрические, объединяет подсемейство Usbekistaniinae. В о $з$ р а с т. Ранний кембрий - голоцен [29].

Подсемейство Turritellellinae Saidova, 1981, emend. Polkovnikova, hic

Turritellellinae: Саидова, 1981. С. 16; Раузер-Черноусова, 1993. С. 51; Usbekistaniidae part.: Вялов, 1968. С. 5; Usbekistaniinae part.: Loeblich, Tappan, 1982. P. 26; 1987. P. 51; Kaminski, 2004. P. 245.

Д и а г н о з. Раковины свободные, спирально-конические, трохоспиральные (трохоидные) или спирально-винтовые, все полностью или только в начальной части, или комбинированные. Вторая камера навита вокруг вертикальной оси разной высоты (от низкой до высокой) в плотную высокую винтовую спираль с небольшим углом расширения (Turritellella Rhumbler, 1904) или в низкую трохоидную спираль с большим расширением (Arenoturrispirilina Tairov, 1956). Или в ранней стадии роста навиты трохоидно, в поздней стадии - в одной плоскости (Ammodiscoides Chushman, 1909). По форме субтреугольные, удлиненно-субцилиндрические. По очертанию 
округлые, овальные или удлиненно-овальные. Р о д о в о й с о с т а в и p а с п р о с т р а н е н и е. 3 рода: Turritellella Rhumbler, 1904 (нижний кембрий - голоцен) [29. P. 99]; Ammodiscoides Chushman, 1909 (средний карбон (московский) - голоцен) [36. Р. 16; 29. Р. 85]; Arenoturrispirilina Tairov, 1956 (келловей - голоцен) [22. Рис. 1; 36. Р. 17]. 3 а м е ч а н и я. Описание подсемейства уточнено автором, а дополнением явилось то, что к подсемейству Turritellellinae отнесены роды, имеющие только свободную раковину (против свободных и прикрепленных у автора подсемейства). В о з р а с т. Ранний кембрий - голоцен [34; 29. Р. 99].

Т и п о в о й р о д: Turritellella Rhumbler, 1904. Turritellella: Rhumbler, 1904, S. 283 (nom. subst. pro Turritellopsis Rhumbler, 1895); Даин, Основы палеонтологии..., 1959. С. 181; Loeblich, Tappan, 1987. P. 52; Turritellopsis: Rhumbler, 1904. P. 289 (nom. correct. pro Turritellopsis Rhumbler, 1895) (non Turriiellopsis Sars, 1878); Turitellopsis: Rhumbler 1895. P. 84 (nom. imperf.); Arturritellum: Rhumbler, 1913. P. 387 (err. emend.). Синонимика рода дана по Леблик и Таппан [12. Р. 52]. Т и п о в о й в и д: Trochammina shoneana Siddal, 1878, современные, северная Атлантика, голотип [Siddal, 1878. P. 46; 12. Pl. 39. Fig. 22, 23; 15. Табл. IX. Фиг. 11]. В о з р а с т. Ранний кембрий - голоцен [34; 29. Р. 99]. В и д о в о й с ос т а в и р а сп р о с т ан е н и е. 4 вида: Turritellella giffordi Hedinger, 1993 [37], верхняя часть нижнего кимериджа Канады, f-слои с Haplophragmoides (?) canuiformis JF39 в интерпретации Б.Л. Никитенко [32. C. 390-391]; Turritellella parva Hedinger, 1993, там же [37]; Turritellella volubilis Gerke et Sossipatrova, 1961, верхний синемюр - верхний плинсбах Западной Сибири [32. Табл. f-4. Фиг. 8, 10].

Подсемейство Usbekistaniinae Vyalov, 1968, emend. Polkovnikova, hic (nom. transl. Loeblich, Tappan, 1982 ex Usbekistaniidae Vyalov, 1968)

Usbekistaniidae part.: Вялов, 1968. С. 5; Turritellellinae part.: Саидова, 1981. С. 16; Раузер-Черноусова. 1993. С. 51; Usbekistaniinae part.: Loeblich, Tappan, 1982. P. 26; 1987. P. 51; Kaminski, 2004. P. 245.

Д и а г н о з. Раковины свободные, спирально-конические, спирально-винтовые. Вторая камера навита вокруг низкой вертикальной оси правильными последовательными оборотами, «как нитки на шпульке», или комбинированно. В поздней стадии роста часть второй камеры навита вокруг оси, расположенной под некоторым углом к начальной части раковины, в одной плоскости (0,5-2 оборота). По форме низкосубцилиндрические. По очертанию округлые или овальные. Р о д о в ой с о с та в и ра с п р с тр ан ен ие. 2 рода: Usbekistania Suleymanov, 1960 (силур? - голоцен) [12. Р. 52]; Repmanina Suleymanov, 1966 (юра - голоцен) [12. Р. 52; 22. Рис. 1; 36. Р. 29]. 3 а м е ч а н и я. Раковины, свободные, навитые вокруг низкой вертикальной оси правильными последовательными оборотами, «как нитки на шпульке», по форме низкосубцилиндрические, объединяет подсемейство Usbekistaninae. Описание подсемейства уточнено автором, а дополнением явилось предложение принять новый типовой вид рода Usbekistania [38. С. 18. Рис. 1. 
Фиг. 4], исключить из рода и подсемейства раковины дисковидной формы [38. С. 18. Рис. 1. Фиг. 1-3] и отнести эти формы к роду Glomospirella и подсемейству Glomospirellinae. В о з р а с т. Силур? - голоцен [12. Р. 51; 15; 29].

Т и п о в о й р о д: Usbekistania Suleymanov, 1960. Glomospirella (Usbekistania) part.: Сулейманов, 1960. С. 18. Рис. 1, Фиг. 4; Usbekistania part.: Loeblich, Tappan, 1964. P. C212 (nom. transl.); 1987. P. 52. Pl. 39. Fig. 20; Discospirella: Fuchs, 1967. P. 260; type species: Discospirella obscura Fuchs, 1967. Т и п о в о й в и д (по автору рода): Glomospirella (Usbekistania) mubarekensis Suleymanov, 1960, голотип: ВНИГРИ, № 517-60, Узбекистан, Бухарский вал, станция Мубарек, скв. 3, глубина 250-260 м, палеоцен [38. С. 18. Рис. 1. Фиг. 1; 12. Pl. 39. Fig. 18]. Т и п о в о й в и д (предлагается автором): Glomospirella (Usbekistania) mubarekensis Suleymanov, 1960 subsp.: ВНИГРИ, № 517-56, Узбекистан, низовье р. Аму-Дарьи, киш. Кара-Узяк, верхний эоцен [38. С. 18. Рис. 1. Фиг. 4; 12. Pl. 39. Fig. 20]. С р а в н е н и е. Род Usbekistania от рода Glomospirella отличается формой раковины (низкосубцилиндрической против дисковидной). В о з р а с т. Силур? - голоцен [12. Р. 52].

Р о д Repmanina Suleymanov, 1966. Repmanina: Сулейманов: Арапова, Сулейманов, I966. C. 122; Loeblich, Tappan, 1987. P. 52. P1. 39. Fig. 24-26. Т и п о в о й в и д: Trochammina squamata Jones et Parker, 1860 var. charoides Jones et Parker, 1860, современный, Тихий океан [Jones et Parker, 1860. P. 304; 39. C. 122]. В и до в ой с ост а в и расп р остран ен ие. Repmanina sp. indet. [ранеe Turritellella volubilis [32. Табл. f-4. Фиг. 9], нижняя юра, верхний синемюр - верхний плинсбах Западной Сибири. С р а в н е н и е. От рода Glomospira отличается типом навивания (спирально-винтовым - вокруг низкой вертикальной оси правильными последовательными оборотами, «как нитки на шпульке», против неправильно клубковидного), формой раковины (низкосубцилиндрической против субсферической, овоидной, уплощенноовоидной, угловато-овоидно-уплощенной). От рода Usbekistania отличается отсутствием оборотов в поздней стадии роста, расположенных в одной плоскости. В о з р а с т.Юра - голоцен [39; 12; 36. Р. 29].

Incertae sedis

Р о д Dolgenia Kemper, 1995 [40. P. 77-78. Taf. 2. Fig. 3, 8-10; Taf. 3. Fig. 1]. Т и п о в о й в и д: Dolgenia convoluta Kemper, 1995, T 527/5 BGR - Ганновер, скв. Долген IV/1, 94,5 м, нижний мел, низы среднего апта, Германия, голотип [40. Taf. 2. Fig. 3].

Д и а г н о з. «Вид и род Tolypammininae, навивание которого первоначально вполне правильное и подобно Ammodiscus образует спираль, но затем становится нерегулярным и приподнимается. Стенка умеренно тонкоагглютинированная» [40. Р. 77]. 3 а м е ч а н и я. На экземплярах, приведенных Е. Кемпер [40. Taf. 2. Fig. 3, 8-10; Taf. 3. Fig. 1], для рода и вида нет следов прикрепления, поэтому непонятно отнесение их к подсемейству Tolypammininae. В ранней стадии роста можно наблюдать как планиспиральное, так и стрептоспиральное навивание; в поздней стадии часть труб- 
чатой камеры отходит от ранней части раковины, выпрямляется или изгибается. Устье округлое в конце трубчатой камеры. В и д о в о й с о с т а в и р а с п р о с т р а н е н и е. 1 вид: Dolgenia [ранее Lituotuba] igarkaensis $(\mathrm{Bu}-$ lynnikova, 1990), верхняя часть верхнего келловея - низы нижнего оксфорда Западной Сибири [13. С. 25-26. Табл. 3. Фиг. 9].

Таким образом, в классе фораминифер подкласса Textulariata отряда Ammodiscida надсемейство Ammodiscoidea объединяет фораминиферы со свободными раковинами в составе четырех семейств: Ammovolumminidae (изогнутые, скрученные или навитые незавершенной спиралью, или с одним оборотом; коротко-конусовидной (слабоизогнутые, сильноизогнутые) или булавовидной формы); Ammovertellinidae (неправильно клубковидные или комбинированные; мономорфные - в виде клубка неправильной формы, субсферические, овоидные, уплощенно-овоидные, угловато-овоидно-уплощенные; гетероморфные - в ранней стадии роста в виде клубка неправильной формы или дисковидные, в поздней стадии - в виде трубки, выпрямленные, прямолинейно-удлиненные или изогнутые: S-образно, U-образно); Ammodiscidae (спирально-плоскостные или комбинированные; обычно мономорфные - дисковидной формы или гетероморфные - в ранней стадии роста дисковидные, в поздней стадии - в виде трубки, выпрямленные или изогнутые); Turritellellidae (спирально-конические; субтреугольной, низкосубцилиндрической, удлиненно-субцилиндрической формы). В семействе Ammodiscidae выделяют два подсемейства - Glomospirellinae (со стрептоспиральным навиванием (определение уточнено автором [22]); обычно мономорфные - дисковидные, слабо двояковыпуклые, слабо выпукловогнутые) и Ammodiscinae (с планиспиральным навиванием или комбинированные; обычно мономорфные - дисковидные или гетероморфные - в ранней стадии роста дисковидные, в поздней стадии - в виде трубки, выпрямленные или изогнутые). В семействе Turritellellidae выделяются два подсемейства - Turritellellinae (трохоспиральные (трохоидные) или спирально-винтовые, все полностью или только в начальной части, или комбинированные; субтреугольной, удлиненно-субцилиндрической формы) и Usbekistaniinae (спирально-винтовые, вторая камера навита вокруг низкой вертикальной оси правильными последовательными оборотами, «как нитки на шпульке», или комбинированно; низкосубцилиндрической формы).

\section{Заключение}

Несмотря на существующие разногласия в определении ранга фораминифер, микропалеонтологи и протозоологи придают важнейшее значение в классификации и выделении таксонов фораминифер морфологии раковины. Микропалеонтологи придают фораминиферам ранг класса, но при этом состав надсемейств, семейств, подсемейств отряда Ammodiscida и их систематическое положение неоднозначны. Автор в качестве главнейшего при- 
знака в выделении отряда Ammodiscida принимает агглютинированный тип стенки кремнистого состава и спиральный характер строения двухкамерной раковины со второй псевдотрубчатой или (и) трубчатой неподразделенной камерой. Для выделения надсемейства Ammodiscoidea основным признаком является свободный характер раковины, выразившийся в отсутствии на раковине следов прикрепления, принимается во внимание, и ряд диагностических признаков (тип строения = тип навивания, форма). Тип строения раковины, обусловленный основным типом навивания второй камеры, является основным морфологическим критерием для выделения семейств, а его разновидности позволяют провести разделение (если это возможно) на подсемейства. Определено таксономическое положение родов и распространенных в юрских отложениях Западной Сибири стратиграфически важных видов надсемейства Ammodiscoidea, с учетом собственных и литературных данных установлено их стратиграфическое распространение.

Благодарю Rachel Bays (Библиотека Университета Женевы), д-ра Андрея Эрнста (Andrej Ernst) (Институт Геологии Университета Гамбурга) за предоставление необходимой литературыз; канд. геол.-мин. наук Л.К. Левчук (Институт нефтегазовой геологии и геофизики им. А.А. Трофимука СО РАН, Новосибирск) и Г.М. Татьянина (Томский государственный университет, Томск), предоставивших автору раковины аммодискусов.

\section{Лumepamypa}

1. Reuss A.E. Entwurf einer systematischen Zusammenstellung der Foraminiferen // Sitzungsber. Kgl. Akad. Wiss. Wien. Math.-naturwiss. Cl. 1862. Bd. 44. S. 355-396.

2. Rhumbler L. Entwurf eines Nattirlichen Systems der Thalamophoren // Nachr. Ges. Wiss. Gottingen. Math.-phys. Kl. 1895. Vol. I. S. 51-98.

3. Cushman J.A. Foraminifera. Their classification and economic use // Cushman Lab. Foram. Research. Spec. Publ. 1928. № 1. 401 p.

4. Chapman F., Parr W.J., Collins A.C. Tertiary foraminifera of Victoria, Australia. The Balcombian deposits of Port Phillip. Part III // Journal of the Linnaean Society of London. Zoologv. 1934. Vol. 38, № 262. P. 553-577.

5. Фурсенко A.B. Основные этапы развития фаун фораминифер в геологическом прошлом // Тр. Ин-та геол. наук АН БССР. 1958. Вып. 1. С. 10-29.

6. Основы палеонтологии. Т. 1 : Общая часть. Простейшие / отв. ред. Д.М. РаузерЧерноусова, А.В. Фурсенко. М. : Изд-во АН СССР, 1959. 482 с.

7. Фораминиферы верхнеюрских отложений Западной Сибири / С.П. Булынникова, Л.Г. Даин, В.Ф. Козырева, В.К. Комиссаренко, В.И. Левина, К.Е. Тылкина : Труды Всесоюз. нефт. науч.-исслед. ин-та. Л. : Недра, 1972. Вып. 317. 272 с.

8. Григялис А.A. О высших таксонах фораминифер. Пелеонтологический журнал. 1978. № 3. C. 3-12.

9. Введение в изучение фораминифер. (Классификация мелких фораминифер мезокайнозоя) / под ред. Субботиной Н.Н., Волошиновой Н.А., Азбель А.Я. Л. : Недра, $1981.211 \mathrm{c}$.

10. Михалевич В.И. Систематика и эволюция фораминифер в свете новых данных по их цитологии и ультраструктуре // Принципы построения макросистемы одноклеточных животных / под ред. М.В.Крылова, Я.И. Старобогатова. Тр. Зоол. ин-та АН СССР. Л. : Наука, 1980. Т. 94. С. 42-61. 
11. Саидова Х.М. О современном состоянии системы надвидовых таксонов кайнозойских бентосных фораминифер. М. : Институт океанологии им. Ширшова АН СССР, 1981. 73 с.

12. Loeblich A.R., Tappan H. Foraminiferal genera and their classification. N.Y. : Van Nostrand Reinhold, 1988 (1987). Vol. 1. 970 p.; Vol. 2. 212 p. Pl. 847.

13. Атлас моллюсков и фораминифер морских отложений верхней юры и неокома Западно-Сибирской нефтегазоносной области. Т. 2 : Фораминиферы / сост.: С.П. Булынникова, В.К. Комиссаренко, Н.А. Белоусова, Е.Д. Богомякова, Г.Е. Рылькова, К.Е. Тылкина. М. : Недра, 1990. 359 с.

14. Маслакова Н.И., Горбачик Т.Н., Алексеев А.С., Барсков И.Н., Голубев С.Н., Назаров Б.Б., Петрушевская М.Г. Микропалеонтология : учебник. М. : Изд-во МГУ, 1995. 256 с.

15. Справочник по систематике фораминифер палеозоя (за исключением эндотироидей и пермских многокамерных лагеноидей) / отв. ред. Д.М. Раузер-Черноусова, Е.А. Рейтлингер. М. : Наука, 1993. 126 с.

16. Lee J.J., Pawlowski J., Debenay J.P., Whittaker J.E., Banner F.T., Gooday A.J., Tendal O., Haynes J., Faber W.W. Class Foraminifera. Lee J.J., Leedale G.F., Bradbury P. (eds), An Illustrated Guide to the Protozoa, second edition. Society of Protozoologists. Lawrence, Kansas : Allen Press. 2000. P. 877-951.

17. Kaminski M.A. The Year 2000 Classification of Agglutinated Foraminifera. In: Bubik M., Kaminski M.A. (eds). Proceedings of the Sixth International Workshop on Agglutinated Foraminifera // Grzybowski Foundation Special Publication. 2004. № 8. P. 237-255.

18. Бугрова Э.М. Практическое руководство по микрофауне. Т. 8 : Фораминиферы кайнозоя / ред. Э.М. Бугрова. СПб. : Изд-во ВСЕГЕИ, 2005. С. 20-32.

19. Подобина В.М. Предлагаемая система фораминифер (высшие таксоны) // Вестник Томского государственного университета. 2014. № 380. С. 215-224.

20. Pawlowski J., Holzmann M., Tyszka J. New supraordinal classification of Foraminifera: Molecules meet morphology // Marine Micropaleontology. 2013. Vol. 100. P. 1-10.

21. Mikhalevich B.I. New insight into the systematics and evolution of the foraminifera // Micropaleontology. 2013. Vol. 59, № 6. P. 493-527.

22. Полковникова E.B. Классификация фораминифер отряда Ammodiscida и надсемейства Tolypamminoidea // Вестник Томского государственного университета. 2015. № 400. C. 404-413.

23. Основы палеонтологии. Членистоногие, трилобитообразные и ракообразные / отв. ред. Н.Е. Чернышева. М. : ГОНТИ, 1960. Т. 8. С. 291-292.

24. Международный кодекс зоологической номенклатуры. Издание четвертое. Принят Международным союзом биологических наук / пер. с англ. и фр. И.М. Кержнера ; ред. перевода А.П. Андрияшев, Я.И. Старобогатов. М. : Т-во научных изданий КМК, 2004. $223 \mathrm{c}$.

25. Коробков И.А. Палеонтологические описания. Л. : Недра, 1978. 208 с.

26. Bender $H$. Test structure and classification in agglutinated foraminifera // Proceedings of the Fourth International Workshop on Agglutinated Foraminifera / M.A. Kaminski, S. Geroch, M.A. Gasinski. Grzybowski Foundation Special Publication. 1995. № 3. P. $27-70$.

27. Поярков Б.В. Развитие и распространение девонских фораминифер. М. : Наука, 1979. 172 с.

28. Черных В.B. Новые позднесилурийские фораминиферы Урала // Палеонтологический журнал. 1967. № 2. С. 37-42.

29. Kaminski M.A., Setoyama E., Cetean C.G. Revised Stratigraphic Ranges and the Phanerozoic Diversity of Agglutinated Foraminiferal Genera // Proceedings of the Seventh International Workshop on Agglutinated Foraminifera / M.A. Kaminski, R. Coccioni (eds.). Grzybowski Foundation Special Publication. 2008. № 13. P. 79-106.

30. Ciarapica G., Zaninetti L. Gandinella apenninica n. gen., n. sp. (foraminifère) dans le Trias superieur (Rhétien, biozone à Triasina Hantkeni du Monte Cetona, Apennin septentrional // Revue de Paléobiologie. 1985. Vol. 4, № 2. P. 307-310. 
31. Сулейманов И.С. О новом роде и виде фораминифер из сем. AMMODISCIDAE // Докл. АН УзССР. 1959. № 7. С. 19-20.

32. Никитенко Б.Л. Стратиграфия, палеобиогеография и биофации юры Сибири по микрофауне (фораминиферы и остракоды). Новосибирск : Параллель, 2009. 680 с.

33. Полковникова E.B. Представители семейства Ammodiscidae Reuss, 1862 в комплексах фораминифер из оксфордских и нижнекимериджских отложений юго-востока Западной Сибири // Эволюция жизни на Земле : материалы IV Международного симпозиума. Томск : ТМЛ-Пресс, 2010. С. 398-402.

34. Culver S. Early Cambrian Foraminifera from West Africa // Science. 1991. № 254. P. 689691.

35. Rhumbler L. Systematische Zusammen-stellung der recenten Reticulosa // Archiv fur Prolisien-kunde. 1904. № 3. P. 181-294.

36. Sepkoski J. A Compendium of Fossil Marine Animal Genera // Bulletins of American Paleontology. 2002. № 363. $560 \mathrm{p}$.

37. Hedinger A.S. Upper Jurassic (Oxfordian-Volgian) Foraminifera from the Husky Formation, Aklavik Range, District of Mackenzie, Northwest Territories // Geological Survey of Canada. 1993. Bull. 439. P. 173.

38. Сулейманов Н.С. Новый подрод и два новых вида из семейства AMMODISCIDAE // Докл. АН УзССР. 1960. № 2. С. 18-20.

39. Арапова Н.Д., Сулейманов Н.С. О фораминиферах из коньякских отложений Западного Узбекистана и Кызылкумов // Ташкентский государственный университет им. В.И. Ленина. 1966. Вып. 273. С.121-127.

40. Kemper E. Abfolge und Verbreitung der Foraminiferen im Barreme und Apt NordwestDeutschlands // Geologisches Jahrbuch. Reihe A: Allgemeine und regionale Geologie BRD und Nachbargebiete, Tektonik, Stratigraphie, Palaeontologie. Hannover. 1995. № 141. P. 63-111.

41. Решение 6-го Межведомственного стратиграфического совещания по рассмотрению и принятию уточненных стратиграфических схем мезозойских отложений Западной Сибири / гл. ред. Ф.Г. Гурари. Новосибирск : СНИИГГиМС, 2004. 114 с., прил. 3 на 31 листе.

Поступила 24.12.2015 г.; повторно 28.02.2016 г.; принята 10.03.2016 г.

Полковникова Елена Валентиновна - н.с. лаборатории микропалеонтологии, геологогеографического факультета Национального исследовательского Томского государственного университета (г. Томск, Россия).

E-mail: polkovnikova@ggf.tsu.ru

Polkovnikova EV. The classification of foraminifera from the superfamily Ammodiscoidea. Vestnik Tomskogo gosudarstvennogo universiteta. Biologiya - Tomsk State University Journal of Biology. 2016;1(33):102-125. doi: 10.17223/19988591/33/7 In Russian, English summary

\section{Elena V. Polkovnikova}

Tomsk State University, Tomsk, Russian Federation

\section{The classification of foraminifera from the superfamily Ammodiscoidea}

The aim of the present paper was to define and determine the taxonomic position of foraminiferal genera and species of the superfamily Ammodiscoidea, which are widely distributed and stratigraphically important for the Jurassic deposits of Western Siberia. Moreover, the micropaleontologists' insight was taken into account as to the 
foraminiferal rank as a class and the group of bicamerate foraminifera with coiled structure, having the second pseudo-tubular or/and tubular indivisible chamber and agglutinated siliceous wall like the order Ammodiscida.

The collections of foraminiferal tests served as the material along with the results of investigation of borehole sections of Western Siberia which we obtained during the scientific exploration. The main feature for isolating the superfamily Ammodiscoidea was a free character of the test manifesting itself in the absence of attachment scars as well as a number of diagnostic signs (a construction type = type of coiling, a form). The test structure depending on the main type of coiling in the second chamber is the principal morphologic criterion for establishing families and its varieties permit dividing (if possible) into subfamilies.

We established that the superfamily Ammodiscoidea comprised four families: Ammovolumminidae Chernykh, 1967, emend. Polkovnikova, hic (curved or coiling, coiled with the incomplete spiral, or with one whorl); Ammovertellinidae Saidova, 1981, emend. Polkovnikova, hic (irregular coiled or combined); Ammodiscidae Reuss, 1862 (planispiral or combined); Turritellellidae Saidova, 1981, emend. Polkovnikova, hic (conical coiled). In the family Ammodiscidae, we distinguished two subfamilies: Glomospirellinae Ciarapica et Zaninetti, 1985, emend. Polkovnikova, hic (with streptospiral coiling) and Ammodiscinae Reuss, 1862 (with planispiral coiling or combined). We proposed that the family Turritellellidae contain two subfamilies: Turritellellinae Saidova, 1981, emend. Polkovnikova, hic (trochospiral (trochiform), as a whole or only in the initial part, or combined) and Usbekistaniinae Vyalov, 1968, emend. Polkovnikova, hic (trochospiral, the second chamber is coiled around the low vertical axis with regular consecutive turns "like the yarn on the bobbin" or combined). The synonyms and re-description of the previously established families and subfamilies are reported in this work. We refined the taxonomic positions of genera and stratigraphically important species occurring in the Jurassic deposits of Western Siberia. The images of the studied genera and species of the superfamily Ammodiscoidea are presented as photos in the Plate).

Acknowledgments: We thank Rachel Bays (University Library of Geneva) and Dr. Andrej Ernst (Institut für Geologie, Universität Hamburg) for providing necessary literature; Cand. Sci (Geol. Min.) LK Levchuk (Trofimuk Institute of Petroleum Geology and Geophysics, Siberian Branch of the Russian Academy of Sciences, Novosibirsk) and GM Tat'janin (Tomsk State University, Tomsk) for providing the author with Ammodiscus tests.

The article contains 1 Plate, 41 References.

Key words: Foraminifera; Ammodiscoidea; classification; composition; distribution; Western Siberia.

\section{References}

1. Reuss AE. Entwurf einer systematischen Zusammenstellung der Foraminiferen. Sitzungsberichte der Kaiserlichen Akademie der Wissenschaften in Wien, MatematischNaturwissenschaftliche Classe. 1862;44(1):355-396. In German

2. Rhumbler L. Entwurf eines Nattirlichen Systems der Thalamophoren. Nachrichten von der Gesellschaft der Wissenschaften zu Göttingen. Mathematisch-Physikalische Klasse. 1895;1:51-98. In German

3. Cushman JA. Foraminifera: their classification and economic use. Cushman Laboratory for Foraminiferal Research Special Publication. 1928;1:401.

4. Chapman F, Parr WJ, Collins AC. Tertiary foraminifera of Victoria, Australia. - The Balcombian deposits of Port Phillip. Part III. Journal of the Linnaean Society of London. Zoology. 1934;38(262):553-577. doi: 10.1111/j.1096-3642.1934.tb00996.x 
5. Fursenko AV. Osnovnye etapy razvitiya faun foraminifer v geologicheskom proshlom [Milestones of foraminifera faunas in the geological past]. Trudy instituta geologicheskikh nauk akademii nauk BSSR. 1958;1:10-29. In Russian

6. Osnovy paleontologii. Obshchaya chast'. Prosteyshie [Fundamentals of paleontology. General part. Protozoa]. Vol. 1. Rauzer-Chernousova DM, Fursenko AV, editors. Moscow: Izdatel'stvo Akademii Nauk SSSR; 1959. 428 p. In Russian

7. Bulynnikova SP, Dain LG, Kozyreva VF, Komissarenko VK, Levina VI, Tylkina KE. Foraminifery verkhneyurskikh otlozheniy Zapadnoy Sibiri [Foraminifera of upper Jurassic deposits in West Siberia]. Trudy Vsesoyuznogo neftyanogo nauchno-issledovatel'skogo instituta - Proceedings of the All-Union Petroleum Research Institute. Vol. 317. Leningrad: Nedra Publ.; 1972. 272 p. In Russian

8. Grigyalis AA. O vysshikh taksonakh foraminifer [On the highest taxa of foraminifers]. Paleontologicheskiy zhurnal - Paleontological Journal. 1978;3:3-12. In Russian

9. Vvedenie $v$ izuchenie foraminifer (Klassifikatsiya melkikh foraminifer mezokaynozoya) [Introduction to the study of foraminifera (Classification of small foraminifera of the MesoCenozoic)]. Subbotina NN, Voloshinova NA, Azbel' AYa, editors. Leningrad: Nedra Publ.; $1981.211 \mathrm{p}$.

10. Mikhalevich VI. Sistematika i evolyuciya foraminifer v svete novyikh dannyikh po ih citologii i ul'trastrukture [Systematics and evolution of the Foraminifera in view of the new data on their cytology and ultrastructure]. In: Printsipy postroeniya makrosistemy odnokletochnykh zhivotnykh. Trudy Zoologicheskogo instituta Akademii Nauk SSSR [Principles of forming the macrosystem of unicellular animals]. Krylova MV, Starobogatova YaI, editors. 1980;94:42-61. In Russian

11. Saidova KhM. O sovremennom sostoyanii sistemy nadvidovykh taksonov kaynozoyskikh bentosnykh foraminifer [The present state of supra-species taxa of Cenozoic benthic foraminifera]. Moscow: Institut okeanologii im. Shirshova Akademii Nayk SSSR Publ.; 1981. 73 p. In Russian

12. Loeblich AR, Tappan H. Foraminiferal genera and their classification. New York: Van Nostrand Reinhold Publ.; 1988(1987). Vol. 1. 970 p.; Vol. 2. 212 p.

13. Bulynnikova SP, Komissarenko VK, Belousova NA, Bogomyakova ED, Ryl'kova GE, Tylkina KE. Atlas mollyuskov i foraminifer morskikh otlozheniy verkhney yury i neokoma Zapadno-Sibirskoy neftegazonosnoy oblasti [Atlas of mollusks and foraminifera of marine deposits of the Upper Jurassic and Neocomian of the West Siberian oil and gas field]. Vol. 2. Moscow: Nedra Publ.; 1990. 359 p. In Russian

14. Maslakova NI, Gorbachik TN, Alekseev AS, Barskov IN, Golubev SN, Nazarov BB, Petrushevskaya MG. Mikropaleontologiya [Micropaleontology]. Moscow: Moscow State University Publ.; 1995. p. 256. In Russian

15. Spravochnik po sistematike foraminifer paleozoya (za isklyucheniem endotiroidey i permskikh mnogokamernykh lagenoidey) [Reference on the Paleozoic foraminifera systematics (except endotiroides and Permian multicellular lagenoides)]. RauzerChernousova DM, Reytlinger EA, editors. Moscow: Nauka Publ.; 1993. 126 p. In Russian

16. Lee JJ, Pawlowski J, Debenay JP, Whittaker JE, Banner FT, Gooday AJ, Tendal O, Haynes J, Faber WW. Class Foraminifera. In: An Illustrated Guide to the Protozoa. Society of Protozoologists. 2nd ed. Lee JJ, Leedale GF \& Bradbury P, editors. Lawrence, Kansas: Allen Press Publ.; 2000. pp. 877-951.

17. Kaminski MA. The Year 2000 Classification of Agglutinated Foraminifera. In: Grzybowski Foundation Special Publication. Proc. of the Sixth International Workshop on Agglutinated Foraminifera. Bubik M, Kaminski MA, editors. 2004;8:237-255.

18. Bugrova EM. Prakticheskoe rukovodstvo po mikrofaune [Practical Guide to microfauna]. Vol. 8. Bugrova EM, editor. St. Petersburg: VSEGEI Publ.; 2005. pp. 20-32. In Russian 
19. Podobina VM. The suggested system of foraminifera (higher taxa). Vestnik Tomskogo gosudarstvennogo universiteta - Tomsk State University Journal. 2014;380:215-224. In Russian, English summary

20. Pawlowski J, Holzmann M, Tyszka J. New supraordinal classification of Foraminifera: Molecules meet morphology. Marine Micropaleontology. 2013;100:1-10. doi: 10.1016/j. marmicro.2013.04.002

21. Mikhalevich VI. New insight into the systematics and evolution of the foraminifera. Micropaleontology. 2013;59(6):493-527.

22. Polkovnikova EV. Classification of foraminifera from order Ammodiscida and superfamily Tolypamminoidea. Vestnik Tomskogo gosudarstvennogo universiteta Tomsk State University Journal. 2015;400:404-413. In Russian, English summary. doi: $10.17223 / 15617793 / 400 / 61$

23. Osnovy paleontologii. Chlenistonogie, trilobitoobraznye i rakoobraznye [Fundamentals of paleontology. Arthropoda, Trilobitomorpha and Crustacea]. Vol. 8. Chernysheva NE, editor. Moscow: GONTI Publ.; 1960. pp. 291-292. In Russian

24. Mezhdunarodnyy kodeks zoologicheskoy nomenklatury. Izdanie chetvertoe [International Code of Zoological Nomenclature. Fourth Edition. Adopted by the International Union of Biological Sciences]. 2nd ed. Kerzhner IM, translated from English and France; Andriyashev AP, Starobogatov YaI, translated editors. Moscow: Tovarishchestvo nauchnykh izdaniy KMK Publ.; 2004. 223 p. In Russian

25. Korobkov IA. Paleontologicheskie opisaniya [Paleontological descriptions]. Leningrad: Nedra Publ.; 1978. 208 p. In Russian

26. Bender H. Test structure and classification in agglutinated foraminifera. In: Grzybowski Foundation Special Publication. Proc. of the Fourth International Workshop on Agglutinated Foraminifera. Kaminski MA, Geroch S. \& Gasinski MA, editors. 1995;3:27-70.

27. Poyarkov BV. Razvitie i rasprostranenie devonskikh foraminifer [Develoment and distribution of Devonian foraminifera]. Moscow: Nauka Publ.; 1979. 172 p. In Russian

28. Chernykh VV. Novye pozdnesiluriyskie foraminifery Urala [New Late Silurian foraminifera of the Urals]. Peleontologicheskiy zhurnal - Paleontological Journal. 1967;2:37-42. In Russian

29. Kaminski MA, Setoyama E, Cetean CG. Revised Stratigraphic Ranges and the Phanerozoic Diversity of Agglutinated Foraminiferal Genera. In: Grzybowski Foundation Special Publication. Proc. of the Seventh International Workshop on Agglutinated Foraminifera. Kaminski MA, Coccioni R, editors. 2008;13:79-106.

30. Ciarapica G, Zaninetti L. Gandinella apenninica n. gen., n. sp. (foraminifère) dans le Trias superieur (Rhétien, biozone à Triasina Hantkeni du Monte Cetona, Apennin septentrional. Revue de Paléobiologie. 1985;4(2):307-310. In French

31. Suleymanov IS. O novom rode i vide foraminifer iz sem. AMMODISCIDAE [On a new foraminifera genus and species from AMMODISCIDAE family]. Doklady akademii nauk UzSSR. 1959;7:19-20. In Russian

32. Nikitenko BL. Stratigrafiya, paleobiogeografiya i biofatsii yury Sibiri po mikrofaune (foraminifery i ostrakody) [Stratigraphy, paleobiogeography and biofacies of the Jurassic of Siberia by microfauna (foraminifera and ostracods)]. Novosibirsk: Parallel' Publ.; 2009. 680 p. In Russian

33. Polkovnikova EV. Predstaviteli semeystva Ammodiscidae Reuss, 1862 v kompleksakh foraminifer iz oksfordskikh i nizhnekimeridzhskikh otlozheniy yugo-vostoka Zapadnoy Sibiri [Representatives of family Ammodiscidae Reuss, 1862 in foraminiferal assemblages from the Oxfordian and Lower Kimmeridgian deposits in the south-east Western Siberia]. In: Evolyutsiya zhizni na Zemle [The evolution of life on Earth. Proc. of the IV Int. Symposium (Tomsk, Russia, 10-12 November, 2010)]. Podobina VM, editor. Tomsk: TML-Press Publ.; 2010. pp. 398-402. In Russian 
34. Culver S. Early Cambrian Foraminifera from West Africa. Science. 1991;254:689-691.

35. Rhumbler L. Systematische Zusammen-stellung der recenten Reticulosa. Archiv fur Prolisien-kunde. 1904;3:181-294. In German

36. Sepkoski J. A Compendium of Fossil Marine Animal Genera. In: Bulletins of American Paleontology. Vol. 364. Ithaca, NY: Paleontological Research Institution; 2002. 560 p.

37. Hedinger AS. Upper Jurassic (Oxfordian-Volgian) Foraminifera from the Husky Formation, Aklavik Range, District of Mackenzie, Northwest Territories. Geological Survey of Canada. 1993. Bull. 439. 173 p.

38. Suleymanov IS. Novyy podrod i dva novykh vida iz semeystva AMMODISCIDAE [A new subgenus and two new species from Ammodiscidae family]. Doklady Akademii Nauk UzSSR. 1960;2:18-20. In Russian

39. Arapova ND, Suleymanov NS. O foraminiferakh iz kon'yakskikh otlozheniy Zapadnogo Uzbekistana i Kyzylkumov [On foraminifera from Coniacian deposits of Western Uzbekistan and the Kyzylkum]. Tashkent: Tashkentskiy gosudarstvennyy universitet im. VI Lenina Publ.; 1966;273:121-127. In Russian

40. Kemper E. Abfolge und Verbreitung der Foraminiferen im Barreme und Apt NordwestDeutschlands [Stratigraphic distribution of Barremian and Aptian foraminifera in Northwest Germany]. Geologisches Jahrbuch. Reihe A: Allgemeine und regionale Geologie BRD und Nachbargebiete, Tektonik, Stratigraphie, Palaeontologie. 1995;141:63-111. In German

41. Reshenie 6-go Mezhvedomstvennogo stratigraficheskogo soveshchaniya po rassmotreniyu i prinyatiyu utochnennykh stratigraficheskikh skhem mezozoyskikh otlozheniy Zapadnoy Sibiri, Novosibirsk, 2003 g. [The decision of the 6th Interdepartmental Stratigraphic Meeting on the consideration and adoption of revised stratigraphic schemes of Mesozoic deposits of Western Siberia, Novosibirsk, 2003]. Gurari FG, editor. Novosibirsk: Siberian Research Institute of Geology, Geophysics and Mineral Resources Publ.; 2004. 114 p. In Russian

Recived 24 December, 2015;

Revised 28 February, 2016; Accepted 10 March, 2016

\section{Author info:}

Polkovnikova Elena V, Researcher, Laboratory of Micropaleontology, Faculty of Geology and Geography, Tomsk State University, 36 Lenin Pr., Tomsk 634050, Russian Federation.

E-mail: polkovnikova@ggf.tsu.ru 